Annales Missiologici Posnanienses t. 25 (2020), s. 57-69

doi: $10.14746 / \mathrm{amp} .2020 .25 .4$

ORCID: 0000-0001-9927-6397

MICHAE ZBOROWSKI

Katolicki Uniwersytet Lubelski Jana Pawła II

\title{
Siedem cech charakteryzujących nową ewangelizację
}

Wezwanie do nowej ewangelizacji, zakomunikowane po raz pierwszy przez papieża Jana Pawła II w 1979 r., stało się stałym elementem rzeczywistości Kościoła ${ }^{1}$. Mimo iż dotyczy ono niezwykle ważnej kwestii, jaką jest troska o zbawienie tych, którzy poznawszy Jezusa Chrystusa, utracili zbawienną z Nim relację, należy z przykrością stwierdzić, że nierzadko funkcjonuje jedynie jako hasło i puste, odmieniane przez wszystkie przypadki nawoływanie. Wciąż wielu teologów, duszpasterzy czy katechetów nie wie, czym jest nowa ewangelizacja, jak należy ją rozumieć i czym różni się od dotychczasowego duszpasterstwa i prowadzonej dotąd ewangelizacji. W konsekwencji można dostrzec istnienie dwóch skrajnych postaw. Jedni na fali entuzjazmu chcą wszystko nazywać nową ewangelizacją, uprawiając swego rodzaju ,pannowoewangelizacjonizm", a drudzy wręcz przeciwnie, zaprzeczają w ogóle potrzebie istnienia „nowej” ewangelizacji. Oba stanowiska mają za podstawę niezrozumienie istoty teologicznej rzeczywistości, jaką stanowi nowa ewangelizacja, a przez to, także licznych jej wypaczeń pastoralnych. Co więcej, wprowadzając zamieszanie epistemologiczne, tendencje te bardziej zniechęcają i gaszą ducha niż motywują do głoszenia Ewangelii.

Już w 1983 r. nastąpiło pierwsze uszczegółowienie rzeczywistości, jaką jest nowa ewangelizacja. Jan Paweł II wskazał, że powinna ona być nowa w swoim zapale, metodach i środkach wyrazu ${ }^{2}$. Z czasem w nauczaniu Kościoła i refleksji teologicznej pojawiły się kolejne dookreślenia i cechy charakterystyczne, a nową ewangelizację zaczęto nazywać konkretnym wezwaniem

${ }^{1} \mathrm{O}$ nowej ewangelizacji nauczają: papież Benedykt XVI i papież Franciszek. Jest ona również przedmiotem refleksji synodów, namysłu teologów oraz działalności duszpasterskiej ruchów i wspólnot kościelnych.

${ }^{2}$ Wypowiedź z dnia 9 marca 1983 r., na spotkaniu z członkami Rady Konferencji Episkopatu Ameryki Łacińskiej (Haiti). 
(Dyk 11). Wzmożony namysł nad ową rzeczywistością doprowadził do tego, że na początku XXI w. istotę nowej ewangelizacji można wyrazić za pomocą siedmiu czynników: nowego kontekstu, nowego odbiorcy, nowego zapału, nowych metod, nowych środków wyrazu, nowych wymagań względem keryksa ${ }^{3}$ oraz nowej treści.

Celem tego artykułu jest zwięzłe omówienie każdego czynnika, jak również wskazanie tych spośród cech charakterystycznych nowej ewangelizacji, które wyróżniają ją na tle innych jej rodzajów. Jeśli niewłaściwe rozumienie wprowadza chaos poznawczy, to poniższy tekst ma służyć uporządkowaniu i lepszemu zrozumieniu poruszanego zagadnienia.

\section{Nowy odbiorca}

Wraz z encykliką Redemptoris missio zdefiniowane zostaje rozróżnienie trzech rodzajów ewangelizacji. Owa systematyzacja przyjęła za kryterium grupy odbiorców, do których adresowane jest przesłanie Ewangelii. W ten sposób papież Jan Paweł II wskazał na misję ad gentes, działalność duszpasterską nazywaną też ewangelizacją zwyczajną i nową ewangelizacją (RMi 33-34). Zaproponowany i wprowadzony przez niego podział został przyjęty i nadal obowiązuje w nauczaniu Kościoła. Odwołują się do niego w swoich dokumentach zarówno papież Benedykt XVI (AM 160), jak i papież Franciszek (EG 14).

Wymienieni biskupi Rzymu są jednomyślni co do charakteryzacji grup adresatów orędzia Dobrej Nowiny. Działalność ad gentes to wymiar misyjny zaangażowania Kościoła skierowany do

narodów, grup ludzi, środowisk społeczno-kulturowych, w których Chrystus i Jego Ewangelia nie są znane, albo w których brak jest wspólnot chrześcijańskich wystarczająco dojrzałych, by mogły wcielać wiarę we własne środowisko i głosić ją innym grupom ludzi (RMi 33).

Zadanie Kościoła, jakim jest zaniesienie Dobrej Nowiny do tych, którzy tęsknią za prawdziwym Bogiem, żyjąc w nieświadomości dzieła zbawczego, dokonanego dla nich przez wcielonego Boga, zawsze zajmowało pierwsze miejsce w działalności Kościoła (RMi 7,40,86).

\footnotetext{
${ }^{3}$ Keryks - herold, zwiastun, publiczny posłaniec lub licytator, czyli ktoś, kto ogłasza lub zwiastuje konkretnie określone orędzie. W kontekście ewangelizacyjnym keryks to człowiek głoszący prawdy Ewangelii, zwane kerygmatem. Więcej na ten temat w punkcie „nowy keryks”.w niniejszym artykule.
} 
Druga grupa obejmuje ludzi wierzących. To ku nim skierowana jest działalność duszpasterska, nastawiona na pogłębienie i rozwój wiary, przyjęcie odpowiedzialności za dawanie świadectwa oraz ukształtowanie stałej zdolności odpowiadania na wezwania miłości Bożej (RMi 33; EG 14). Takie cele można stawiać przed osobami ochrzczonymi, które są członkami Kościoła, trwają w relacji z Jezusem Chrystusem poprzez słowo Boże i sakramenty, a także angażują się aktywnie w życie wspólnotowe. Adresatem tego rodzaju ewangelizacji są więc ludzie świadomie przeżywający wiarę i świadomie postrzegający zobowiązania z niej wynikające oraz kształtujący swoją codzienność i wybory życiowe w świetle Ewangelii.

Pomiędzy misją ad gentes a duszpasterstwem, jak stwierdza Jan Paweł II,

istnieje sytuacja pośrednia, zwłaszcza w krajach o chrześcijaństwie dawnej daty, ale czasem również w Kościołach młodych, gdzie całe grupy ochrzczonych utraciły żywy sens wiary albo wprost nie uważają się już za członków Kościoła, prowadząc życie dalekie od Chrystusa i od Jego Ewangelii. W tym wypadku zachodzi potrzeba „nowej ewangelizacji” albo „re-ewangelizacji” (RMi 33).

Nowa ewangelizacja skierowana jest do ludzi, którzy zaniechali praktyk chrześcijańskich (AM 160), oraz do środowisk i krajów, gdzie Ewangelia została zapomniana lub spotyka się z rozpowszechnioną z powodu szerzącego się sekularyzmu obojętnością (VD 122). Papież Benedykt XVI dopowiada, że „wielu chrześcijan potrzebuje, aby na nowo głoszono im z przekonaniem słowo Boże, by mogli konkretnie doświadczyć mocy Ewangelii. Tylu jest braci “ochrzczonych, ale niewystarczająco zewangelizowanych"” (VD 96). Podobnie twierdzi papież Franciszek, pisząc, że tyle jest „'osób ochrzczonych, które jednakże nie żyją zgodnie z wymogami chrztu świętego', nie przynależą całym sercem do Kościoła, nie doświadczają już pociechy płynącej z wiary” (EG 14).

Trzeci rodzaj ewangelizacji zamierza zatem otoczyć troską duszpasterską tych, którzy, mimo iż słyszeli o Jezusie Chrystusie, a nawet stali się członkami Kościoła poprzez chrzest, to jednak z rozmaitych powodów utracili wiarę. Są oni formalnymi lub nominalnymi chrześcijanami, których życie przypomina bardziej życie człowieka niewierzącego niż wierzącego. Będąc „ochrzczonymi poganami”, nie podejmują życia Ewangelią i nie korzystają z dóbr duchowych, płynących z łaski sakramentu chrztu. Nie doświadczają mocy Ewangelii, ponieważ manifestuje się ona dopiero w życiu wierzących (por. Rz 1,16), dlatego Kościół wychodzi do nich z orędziem kerygmatu, aby mogli spotkać Jezusa Chrystusa i doświadczyć zbawienia. Należy zaznaczyć, że liczba takich chrześcijan nieustannie wzrasta, a w literaturze teologicznej oraz praktyce duszpasterskiej coraz częściej dla zobrazowania tej tendencji przytacza się przypowieść Zbawiciela o zagubionej owcy (por. Łk 15,1-7), z tą 
jednak różnicą, że obecnie tylko jedna owieczka ze stu zostaje przy swoim Pasterzu, Jezusie Chrystusie, w owczarni, jaką jest Kościół, a pozostałe dziewięćdziesiąt dziewięć oddala się od wspólnoty.

\section{Nowy kontekst}

Nowym kontekstem określa się współczesny, zsekularyzowany i postchrześcijański świat (Cantalamessa, Come la scia 54). Jego cechami charakterystycznymi są: skrajny materializm, scjentyzm oraz ideologie negujące Boga, w zamian proponujące świeckie zbawienie, relatywizm, wojujący ateizm, kult rozumu i kult pieniądza. Żyjący w takim świecie człowiek jest coraz bardziej pragmatyczny, nastawiony na zysk oraz używanie życia. Dąży do samorealizacji, żyje tu i teraz, często bezrefleksyjnie i obojętnie. Liczy na rozwój nauki i techniki, który ma mu przynieść odpowiedzi na wszelkie bolączki jego egzystencji. Jednak konsekwencją takiej wizji świata jest wielkie zagubienie człowieka, który coraz częściej sam nie wie, kim jest, jaki jest jego początek oraz czy istnieje jakiś sens i cel jego życia. Obecny, zsekularyzowany, wysoce rozwinięty technologicznie oraz kulturowo, a także opływający w bogactwa świat, który obwieszcza, że wszystko jest możliwe i osiągalne, stawia na swoją samowystarczalność. Boga uznaje za niepotrzebnego i ograniczającego wolność. Jest to czas ogromnego postępu cywilizacyjnego, w którym świat i człowiek utracili zdolność do życia w harmonii z Bogiem, tym samym pozbawiając się możliwości zrozumienia samych siebie.

Co więcej, prądy filozoficzno-kulturowe wieków XX i XXI, systemowo kształtując mentalność współczesnego świata i człowieka, wpływają na tworzenie wizji świata bez Boga. Ich wspólnym mianownikiem jest negacja lub zastępowanie Boga oraz konieczności rozumianego duchowo lub religijnie zbawienia. Promuje się wiele substytutów mających zastąpić człowiekowi rzeczywistość soteriologiczną.

Zdecydowanie współczesny kontekst nie sprzyja rozwojowi rzeczywistości wiary człowieka. Prądy antyreligijne, podbudowane filozoficznie i naukowo, ośmieszają oraz zwalczają wszelkie przejawy jego pobożności i wiary, a także upowszechniają klimat obojętności religijnej, propagując mentalność sekularystyczną, jak również postawy agnostycyzmu i ateizmu (Ferdek 21). Sytuacja ta nie pozostaje bez wpływu na ludzi wierzących (Kowalczyk 48-53). W wymiarze eklezjalnym mamy do czynienia z powstaniem nowej grupy. Stanowią ją ci, którzy formalnie stali się członkami Kościoła przez chrzest, ale nigdy nie poznali osobiście Jezusa Chrystusa. Wiara jest dla nich jedynie tradycją i zbiorem przykazań. Ludzi tych można określić mianem: nominalni chrześcijanie lub „ochrzczeni poganie”, bo choć mają oni udział w godności 
chrześcijańskiej i są częścią mistycznego Ciała Chrystusa, to jednak żyją tak, jak ludzie obojętni i niewierzący, z dala od Kościoła i sakramentów. Wiara nie stanowi żadnego punktu odniesienia w ich życiu ${ }^{4}$. To oni właśnie są adresatem rzeczywistości nowej ewangelizacji.

\section{Nowy zapal}

Jednym z pierwszych opisów nowej ewangelizacji było sformułowanie użyte przez Jana Pawła II, że powinna ona być nowa pod względem zapału, metod i środków wyrazu. Pod tymi określeniami kryje się głęboka treść oraz kierunek, jaki papież wyznaczył nowej ewangelizacji. Nowy zapał wskazuje na potrzebę odnowienia przestrzeni pasji i całoosobowego zaangażowania w dzieło ewangelizacji (Cantalamessa, Przygotujcie 17). Brak zapału do głoszenia Jezusa Chrystusa jest znakiem osłabienia wiary (RMi 2), dlatego Kościół, z natury misyjny, powinien ponownie odnaleźć to wielkie pragnienie głoszenia Ewangelii, jakie miał w swoich początkach. Owa gorliwość i entuzjazm rodzą się z osobistego spotkania z Jezusem Chrystusem. Dlatego wskazanie nowego zapału odsyła, w wymiarze indywidualnym, do przestrzeni modlitwy, formacji i rozwoju duchowego, aby doświadczając zbawczej relacji z Bogiem, keryks nie mógł nie głosić tego, co widział, tego, co słyszał i tego, co jest jego udziałem (por. Dz 4,20; $1 \mathrm{~J}$ 1,1-4). Odsyła ono także do wymiaru wspólnotowego, zapraszając Kościół do autoewangelizacji. Zgodnie z formułą: Ecclesia reformata et semper reformanda est Kościół, jeśli chce ewangelizować, musi także poddawać się ewangelizacji i stale odnawiać swoje doświadczenie spotkania z Jezusem Chrystusem. Ono zawsze owocuje odnowionym zapałem i gorliwością ewangelizacyjną. Należy również łączyć nowy zapał z wymiarem pneumatologicznym (Krzemiński 256-258). To trzecia Osoba Trójcy Świętej jest duszą ewangelizacji (Pawłowski 58) i to Ona umożliwia spotkanie z Jezusem Chrystusem, a później pobudza i rozpala serca, dając niezbędną, duchową moc do głoszenia Jezusa Chrystusa (Prado Flores 52).

\section{Nowa metoda}

Nowa ewangelizacja to, jak zauważa Stanisław Dyk, przede wszystkim odnowienie metodologiczne dotychczasowej ewangelizacji (Dyk 59). We wska-

\footnotetext{
${ }^{4}$ Podobnie opisał adresata orędzia nowej ewangelizacji Stanisław Dyk. Wskazuje on na trzy cechy charakterystyczne takiego odbiorcy. Według niego są nimi: „brak żywej wiary (osobowej relacji z Bogiem), utrata więzi z Kościołem, życie poza perspektywą Ewangelii” (Dyk 51).
} 
zaniu papieża na nową metodę chodzi o znalezienie takiego postępowania lub strategii, która umożliwi, w kontekście zsekularyzowanego świata, dotarcie $\mathrm{z}$ orędziem Ewangelii do współczesnego człowieka w celu doprowadzenia go do żywej i zbawczej relacji z Bogiem. Jednak ze względu na wielość kulturowych wyzwań i różnorodność zjawisk społeczno-religijnych w rozmaitych częściach świata utrudnione jest wypracowanie jednej, adekwatnej i obowiązującej wszędzie metody (Parzych 123). Jednakże nie zmienia to faktu, że pewne zasadnicze kierunki, z racji podobnych tendencji współczesnego świata, będą zasadniczo wspólne.

Mówiąc o nowej metodzie w nowej ewangelizacji, wskazuje się w pierwszym rzędzie na metodę kerygmatyczną (Cantalamessa, Przygotujcie 17). To właśnie „pierwsze orędzie” stanowi główną treść przepowiadania, gdyż jako słowo skuteczne i rodzące wiarę (por. Rz 10,17) jest właściwą drogą we współczesnym kontekście do zrealizowania celu nowej ewangelizacji. Pozwala doświadczyć osobowego spotkania z Jezusem Chrystusem w Duchu Świętym, przemienia życie człowieka i wprowadza w przestrzeń wiary. Zastosowanie metody kerygmatycznej zakłada także przyjęcie pewnej kolejności w przekazywaniu Ewangelii. Na początku głosi się kerygmat, a dopiero później następuje przekaz katechetyczny i mistagogia. Najpierw należy zrodzić do żywej wiary, a dopiero później wprowadzać treści dogmatyczne czy moralne (Ryś 5-6). W tej metodzie ważne jest także dawanie świadectwa, czyli ukazanie zbawczej interwencji Boga w życiu przekazującego orędzie Ewangelii. Współczesny świat bardziej słucha świadków, aniżeli nauczycieli, a jeśli słucha nauczycieli to tylko dlatego, że są oni świadkami (EN 41). Metoda kerygmatu strukturalnie składa się więc z głoszenia kerygmatu połączonego z dzieleniem się świadectwem. Nową metodę można zawrzeć w stwierdzeniu: głosić kerygmat, będąc świadkiem i pamiętając, że pierwsze jest pierwsze.

Jako metoda w duchu nowej ewangelizacji, metoda kerygmatyczna ${ }^{5}$ została przyjęta przez liczne grupy, wspólnoty i ruchy formacyjno-ewangelizacyjne Kościoła katolickiego (Zborowski), często też stając się główną strategią ich działania. Poza tą najbardziej podstawową metodą występuje w literaturze jeszcze kilka metod charakterystycznych dla nowej ewangelizacji, a wśród nich metoda misyjna, obecna bardzo mocno w nauczaniu Ojca Świętego Franciszka, zwana także metodą wychodzenia (EG 20,46; ChV 164,222; QA 98). Jej podstawę stanowi zmiana mentalności w prowadzeniu duszpasterstwa, które nie ma być już jedynie uprawną rolą lub doglądaniem owiec, ale wychodzeniem po te, które zagubiły się i same do Kościoła nie przyjdą (Canta-

\footnotetext{
${ }^{5}$ Nazywana jest także ewangelizacją kerygmatyczną lub chrystologiczną. Jej istota polega na skoncentrowaniu się na Chrystusie i dążeniu do doprowadzenia ludzi do osobowego uznania i wyboru Jezusa Chrystusa jako Pana i Zbawcy.
} 
lamessa, Come la scia 63; Dyk 65-66). Z ową metodą wiąże się nawrócenie pastoralne ewangelizatorów, wejście $\mathrm{w}$ środowisko życia codziennego tych, którzy utracili wiarę i tam ukazanie im Boga z pomocą odpowiednio dostosowanego języka. Podstawowymi kategoriami tej metody są: wyjście, szukanie i inkulturacja.

Inną metodą pośrednio związaną z nową ewangelizacją, a w zasadzie przygotowującą jej realizację jest strategia ożywania wiary wierzących i wspólnot kościelnych (Cantalamessa, Come la scia 63). Strategia ta zakłada wpierw zewangelizowanie lub odnowienie doświadczenia spotkania Boga u osób uczęszczających do Kościoła, by potem głosiły one Ewangelię. Jednocześnie owa strategia uwzględnia kontekst współczesnego świata oraz charakterystykę osób szczególnie powołanych do ewangelizowania na tym etapie dziejów ${ }^{6}$. Jest to więc autoewangelizacja, która ma doprowadzić do bycia świadomym odpowiedzialności za ewangelizację i która ma wzbudzić zapał misyjny wśród wszystkich członków Kościoła. Niezastąpioną rolę w tej dziedzinie odgrywają wspólnoty, w których można doświadczyć nie tylko ewangelizacji, ale i formacji ku ewangelizacji. Metoda ożywiania wiary, zwłaszcza wśród ludzi świeckich, jest niezwykle istotna w obecnym czasie, bowiem dzielą oni obszar życia, pracy, spędzania wolnego czasu, aktywności politycznej czy społecznej z osobami zdechrystianizowanymi i niewierzącymi. Metoda ta opiera się na doprowadzeniu do żywej relacji z Jezusem Chrystusem, w której ewangelizowany odkryje swoje wezwanie do świadczenia o Tym, w którego wiarę wyznał jako w swego Zbawiciela i Pana.

\section{Nowe środki wyrazu}

Trzecią rzeczywistością, na którą wskazał w 1983 r. papież Jan Paweł II, są nowe środki wyrazu. Jak stwierdził jeden z duszpasterzy, w ewangelizacji przegrywamy nie przez to, co głosimy, bo nie ma lepszego orędzia niż zbawienie w Jezusie Chrystusie, ale przez to, jak głosimy (Projekt Pastoralny 5). W procesie ewangelizacji należy wykorzystać współczesny dorobek techniczno-technologiczny, aby jeszcze skuteczniej, ze względu na formę rozumianą właśnie jako środki wyrazu, głosić Ewangelię. Ze współczesnego, wysoce rozwiniętego świata należy przede wszystkim zaczerpnąć wiedzę o komunikacji oraz rozwiązania i innowacje techniczne, służące szybkiemu i dostosowanemu do mentalności komunikowaniu. Jest to zgodne z założeniami inkulturacji, która zakłada wykorzystanie takich elementów danej kultury, które pomogą w ,zwiastowaniu” Ewangelii (Cantalamessa, Tchnienie 143). Dodatkowo nowe

\footnotetext{
${ }^{6}$ Więcej na ten temat w punkcie: Nowy keryks.
} 
środki wyrazu powinny uwzględniać dostosowanie języka do sposobu komunikowania i wspomniane już do mentalności ludzi. Ten kierunek nowej ewangelizacji wskazuje na potrzebę adaptacji Ewangelii we współczesnej kulturze i wyrażenia jej za pomocą właściwych owej kulturze środków.

\section{Nowy keryks}

Istotnym wyróżnikiem nowej ewangelizacji jest głoszący kerygmat keryks i nowa charakterystyka jego roli, przygotowania oraz cech istotnych dla jego posługi w zsekularyzowanym świecie. Adhortacja apostolska Evangelii gaudium określa podmiot $\mathrm{w}$ dziele nowej ewangelizacji, którym, według papieża Franciszka, jest każdy ochrzczony członek Ludu Bożego, ubogacony osobistym doświadczeniem miłości Bożej i zbawienia (EG 120). Co więcej, papież dodaje, że „każdy chrześcijanin jest misjonarzem w takiej mierze, w jakiej spotkał się z miłością Boga w Chrystusie Jezusie" (EG 120). Istotę bycia keryksem stanowi więc przyjęcie przez niego sakramentu chrztu i osobiste spotkanie z Jezusem Chrystusem. W pewnym sensie nie jest to nic odkrywczego i nowego, ponieważ wynikające z chrztu powszechne powołanie do głoszenia Ewangelii zawarte jest chociażby w Apostolicam Actuositatem, Evangelii nuntiandi, Redemptoris missio czy w Katechizmie Kościoła Katolickiego. Zazwyczaj jednak sprowadzało się ono do świadectwa życia, pozostawiając przestrzeń ewangelizacji i świadczenia słowem osobom do tego przygotowanym.

Dzisiaj jednak „należy odrzucić myślenie o tylko wykwalifikowanych pracownikach w dziele ewangelizacji” (EG 120). Papież Franciszek ukazuje zupełnie nową perspektywę związaną ze specyfiką współczesnego odbiorcy. Ludzie, do których skierowana jest nowa ewangelizacja, nie potrzebują, przynajmniej na samym początku, szczegółowych i zaawansowanych zagadnień teologicznych albo filozoficznych dowodów na istnienie Boga (w związku z tym keryks nie musi być wykwalifikowanym teologiem), lecz ukazania, że Bóg jest i może realnie działać w konkrecie ludzkiego życia. W pierwszej kolejności liczy się bycie świadkiem. Odpowiedzią na oziębłość i brak wiary współczesnych ludzi jest głoszenie najprostszych prawd wiary zawartych w kerygmacie ${ }^{7}$ oraz pokazanie, w jaki sposób przemieniły one życie keryksa, a do tego nie potrzeba „wielu lekcji lub długich pouczeń” (EG 120). Każdy uczeń jest jednocześnie misjonarzem powołanym do głoszenia Dobrej Nowi-

\footnotetext{
${ }^{7}$ Istnieje wiele rozmaitych schematów określających zawartość treściową kerygmatu. Najbardziej znany jest model sześciopunktowy, obejmujący głoszenie Dobrej Nowiny o miłości Bożej, grzechu człowieka, zbawieniu w Jezusie Chrystusie, wierze i nawróceniu, darze Ducha Świętego i rzeczywistości Kościoła.
} 
ny i dzielenia się, czyli do opowiadania o swoim spotkaniu z Jezusem Chrystusem.

Popatrzmy na pierwszych uczniów, którzy natychmiast po doświadczeniu spojrzenia Jezusa, szli głosić Go pełni radości: „Znaleźliśmy Mesjasza” (J 1,41). Samarytanka, tuż po zakończeniu swego dialogu z Jezusem, stała się misjonarką i wielu Samarytan uwierzyło w Jezusa „dzięki słowu kobiety" (J 4,39). Również św. Paweł po swoim spotkaniu z Jezusem Chrystusem „zaraz zaczął głosić w synagogach, że Jezus jest Synem Bożym” (Dz 9,20) (EG 120).

Nowość w nauczaniu papieża Franciszka wynika z dobrej analizy rzeczywistości i zinkulturowanego doboru osoby keryksa do kontekstu współczesności. Spośród wielu obecnych w nauczaniu teologicznym wymagań stawianych głosicielom Ewangelii, wiodących dla nowych ewangelizatorów w dobie nowej ewangelizacji, papież Franciszek wyróżnia dwa: chrzest i osobiste doświadczenie spotkania Boga w życiu głoszącego. Nie oznacza to wcale, że nie trzeba przygotowywać się do misji, rozwijając się duchowo czy intelektualnie, np. ucząc się nazywania swoich doświadczeń duchowych bądź poznając treści kerygmatu. Nie jest to jednak takie samo przygotowanie, jakiego wymaga się od katechetów i formatorów pracujących w dziele ewangelizacji zwyczajnej, czyli w duszpasterstwie, a tym bardziej od wykładowców teologii czy misjonarzy. Nie oznacza to także przekreślenia pozostałych kryteriów dobrego głosiciela Słowa, ale oznacza jedynie wskazanie tych niezbędnych (sine qua non), które, ze względu na współczesny, zsekularyzowany świat, powinny cechować keryksa.

\section{Nowa treść}

Ostatnią, charakterystyczną cechą nowej ewangelizacji jest nowa treść. Czym ona jest i jak należy rozumieć jej nowość? W zrozumieniu tego zagadnienia pomocna staje się refleksja kaznodziei Domu Papieskiego Raniera Cantalamessy, który podkreśla, że „odnowa polega na odkryciu i zaproponowaniu tych elementów Słowa Bożego, które najbardziej odpowiadają potrzebom dzisiejszego człowieka, aby uprzywilejować je w przepowiadaniu odpowiednim dla dzisiejszej kultury" (Cantalamessa, Tchnienie 143). W innym miejscu dopowiada, że ,podstawowa zasada chrześcijańskiego przepowiadania brzmi: 'Głosić Chrystusa w Duchu Świętym' lub 'Głosić Ewangelię mocą Ducha Świętego" (Cantalamessa, Tajemnica 44). Zatem najistotniejszą treścią przepowiadania jest Osoba Jezusa Chrystusa będącego Ewangelią. To przesłanie stanowi centrum kerygmatu już od czasów apostolskich. Apostołowie głosili Dobrą Nowinę, obwieszczając, że Jezus Chrystus jest Człowiekiem i Bo- 
giem, a także przepowiadali dwa wydarzenia zbawcze z Jego życia - śmierć i zmartwychwstanie, samego Jezusa nazywając Panem, Zbawicielem i Mesjaszem. O wspomnianej nowości ewangelizacji papież Jan Paweł II mówi, że:

nie dopuszcza zmiany treści orędzia ewangelicznego, ponieważ Chrystus jest ten sam wczoraj, dziś i na wieki. Ewangelię trzeba głosić wiernie i bez zniekształceń. Aby była prawdziwa ewangelizacja, trzeba głosić imię i naukę, życie i obietnice, Królestwo i tajemnice Jezusa Nazareńskiego, Syna Bożego (Jan Paweł II 24-25).

Jednak na przestrzeni wieków zmieniał się charakter i zakres treści kerygmatu. Nazywany chrystologicznym credo, nadal przekazywał treści dotyczące Osoby Jezusa Chrystusa i Ewangelii, ale pogłębione o zagadnienia dogmatyczne, moralne czy praktyczno-ascetyczne. Pojęcie kerygmatu, obejmując kolejne wymiary teologii i przestrzenie praktyki duszpasterskiej, stawało się coraz szersze. $Z$ czasem doszło do tego, że kerygmatem, czyli Dobrą Nowiną, nazywano każdą formę głoszenia i niemal każdą treść teologiczną ${ }^{8}$.

Kerygmat jest pierwszym przepowiadaniem. Inicjalny aspekt tego orędzia ma podwójny wymiar. $Z$ jednej strony kerygmat rodzi do wiary, dając nowe życie i urzeczywistniając łaskę zbawienia w życiu jego odbiorcy, a z drugiej jest on punktem wyjścia dla rozwoju katechezy, moralności, pogłębiania prawd wiary, kształtowania się dogmatów. Od niego, jak od zalążka, rozpoczyna się teologia. Można zauważyć, że jest on początkiem zarówno w znaczeniu egzystencjalno-soteryjnym, jak i w znaczeniu teoretyczno-dogmatycznym. Jednakże czym innym jest głoszenie kerygmatu, a czym innym dogmatów: pierwsze to głoszenie Chrystusa, a drugie to głoszenie o Chrystusie.

\footnotetext{
${ }^{8}$ Kerygmat $(\kappa \eta \rho v \gamma \mu \alpha)$ w języku oryginalnym oznacza zarówno treść przekazu, jak i czynność głoszenia, co implikuje podwójne ujęcie. Można mówić o kerygmacie w aspekcie materialnym i formalnym. Ponadto z upływem czasu, wraz z rozwojem tego pojęcia i jego zastosowania w historii Kościoła, pojawia się również rozumienie kerygmatu w sensie ścisłym i szerokim. Określenie ścisłe oznacza uroczystą i publiczną proklamację zbawienia dokonanego przez Jezusa Chrystusa, najczęściej odnoszącą się do wydarzenia Jego śmierci i zmartwychwstania, zakończoną wezwaniem do wiary i nawrócenia. Kerygmat w sensie ścisłym (vel pierwotnym) oznacza konkretnie określoną treść oraz formę, jaką jest ustne przepowiadanie. Jeśli chodzi o szersze znaczenie, istnieją w literaturze pewne rozbieżności. Niektórzy uważają kerygmat w sensie szerokim za każdą formę kościelnego przepowiadania, odnosząc się jedynie do kerygmatu jako czynności głoszenia. Takie spojrzenie pojawia się wraz z rozwojem kaznodziejstwa średniowiecznego i trwa nadal. Jednak ujęcie ze względu na formę poszerza nam równocześnie zakres treści głoszonych w tak rozumianym kerygmacie, ponieważ wszystko, co jest głoszone, będzie nosiło miano kerygmatu. Inni natomiast twierdzą, że kerygmat w sensie szerokim to komunikowanie treści prawd wiary niezawężonych jedynie do misterium paschalnego Jezusa Chrystusa. Takie przekonanie obecne jest w myśli teologicznej, począwszy od epoki Ojców Kościoła. Kerygmat jest więc szerokim wykładem i pogłębieniem Dobrej Nowiny. Wyznacznik stanowi materia kerygmatu, co implikuje, że może być on przekazywany także w innych formach niż jedynie w formie, jaką jest ustna proklamacja.
} 
Jako cecha charakterystyczna nowej ewangelizacji, nowość treści polega na podwójnym powrocie do pierwotnego rozumienia kerygmatu: treściowego i znaczeniowego. W kontekście nowej ewangelizacji, a więc wspomnianych już rzeczywistości współczesnego, zsekularyzowanego świata i jasno określonego odbiorcy, właściwym przekazem jest kerygmat w sensie ścisłym: najbardziej fundamentalne treściowo przesłanie o zbawieniu w Jezusie Chrystusie. Zestawiając bowiem czasy pierwotnego Kościoła ze współczesnym kontekstem, dostrzec można wiele podobieństw. Na tej podstawie zasadne wydaje się, że najlepszą reakcję i odpowiedź Kościoła, jakiej można udzielić, stanowi orędzie kerygmatyczne. Należy także zauważyć, że powrót do pierwotnego głoszenia Jezusa umarłego i zmartwychwstałego wiąże się również z ponownym podkreśleniem znaczenia i roli kerygmatu jako początku wiary. W kerygmacie urzeczywistnia się zmartwychwstanie, a żywy Jezus w Duchu Świętym czyni wszystko nowe w życiu ewangelizowanego. Jest to powrót do wymiaru egzystencjalno-zbawczego pierwszego orędzia. W nowej ewangelizacji nie skupia się uwagi na tym, że kerygmat daje początek Kościołowi, dogmatom czy całej teologii, ale przede wszystkim na tym, że daje on początek życiu wiary.

Reasumując, do cech charakterystycznych nowej ewangelizacji (będących owocem analizy nauczania Kościoła i szerokiej refleksji dogmatyczno-pastoralnej) zalicza się: nowy kontekst, w którym głosi się Ewangelię, nowego odbiorcę tego orędzia, a także wskazany przez Jana Pawła II nowy zapał, nowe metody i nowe środki wyrazu. Należy też wskazać właściwy wybór nowego kryksa oraz treść, jaką stanowi kerygmat sensu stricto. W ten sposób wyraźnie widać, że nowa ewangelizacja, jako jeden z trzech mających miejsce w Kościele rodzajów ewangelizacji, jest zadaniem konkretnym i precyzyjnie określonym. Wszelkie próby jej absolutyzowania czy podważania jawią się jako niezbyt poważne i teologicznie nieuzasadnione.

Warto jednak zaznaczyć, że cechy charakterystyczne nowej ewangelizacji, omówione w powyższym artykule, nie są równoznaczne z tym, co odróżnia nową ewangelizację od misji ad gentes czy duszpasterstwa, ponieważ każdy rodzaj ewangelizacji ma miejsce obecnie w nowym, nieprzyjaznym wierze kontekście kultury zsekularyzowanej. Inaczej wpływa on na działalność misyjną, inaczej na duszpasterstwo - nie towarzyszy tylko rzeczywistości nowej ewangelizacji. Wydaje się również oczywiste, że nowy zapał oraz użycie nowych środków wyrazu powinno być obowiązkowe w absolutnie każdej działalności ewangelizacyjnej Kościoła. Trudno bowiem wyobrazić sobie prowadzenie duszpasterstwa czy działalności misyjnej bez nowoczesnych osiągnięć technicznych i technologicznych, a już tym bardziej prowadzenie ich przez osoby bez żywej relacji z Jezusem Chrystusem. Wydaje się więc, że do cech wyróżniających nową ewangelizację należy zaliczyć jedynie nowego odbio- 
rę oraz nowego keryksa, a także, pomimo, że pierwsze orędzie jest również właściwym narzędziem ewangelizacji ad gentes, treść przepowiadania, jaką stanowi kerygmat sensu stricto. Owe trzy cechy charakterystyczne są jednocześnie cechami wyróżniającymi ten rodzaj ewangelizacji.

\section{SEVEN CHARACTERISTICS OF THE NEW EVANGELIZATION}

\section{Summary}

The new evangelization is a concrete task, precisely described in the documents and teaching of the Church. Its characteristic features include: a new context in which the Gospel is proclaimed, a new recipient of this message, a new enthusiasm, new methods, new means of expression, as well as a new keryx and a new content, which is the kerygma sensu stricto. The new evangelization is one of the three types of evangelization in addition to the mission ad gentes and the ordinary evangelization.

Keywords: new evangelization; keryx; kerygma; newness; preaching

Słowa kluczowe: nowa ewangelizacja; keryks; kerygmat; nowość; przepowiadanie

\section{Wykaz skrótów}

AM - Benedykt XVI, Adhortacja apostolska Africae minus [19.11.2011]
ChV - Franciszek, Adhortacja apostolska Christus vivit [25.03.2019]
EG - Franciszek, Adhortacja apostolska Evangelii gaudium [24.11.2013]
EN - Paweł VI, Adhortacja apostolska Evangelii nuntiandi $[8.12 .1975]$
QA - Franciszek, Adhortacja apostolska Querida Amazonia $[2.02 .2020]$
RMi - Jan Paweł II, Encyklika Redemptoris missio [7.12.1990]
VD - Benedykt XVI, Adhortacja apostolska Verbum Domini [30.09.2010].

\section{BIBLIOGRAFIA}

Benedykt XVI. Adhortacja apostolska Africae munus. Kraków: Wydawnictwo AA, 2012.

Benedykt XVI. Adhortacja apostolska Verbum Domini. Kraków: Wydawnictwo M, 2010.

Cantalamessa, Raniero. Come la scia di un vascello. Orizzonti per una nova evangelizzazione. Milano: Edizioni San Paolo, 2012.

Cantalamessa, Raniero. Przygotujcie drogi Pańskie. Tłum. Krystyna Kozak. Kraków: Wydawnictwo Księży Sercanów, 1999.

Cantalamessa, Raniero. Tajemnica głoszenia Słowa Bożego. Tłum. Grzegorz Niedźwiedź. Wrocław: Franciszkańskie Wydawnictwo św. Antoniego, 2007. 
Cantalamessa, Raniero. Tchnienie Ducha. Tłum. Krystyna Kozak. Częstochowa: Edycja Świętego Pawła, 1998.

Dyk, Stanisław. Nowa ewangelizacja. Konkretne wyzwanie. Gubin: Przystanek Jezus, 2015.

Ferdek, Bogdan. „Duchowość jako interioryzacja dogmatu.” Studia Gnesnensia (2017) XXXI: 19-31.

Franciszek. Adhortacja apostolska Christus vivit. Kraków: Wydawnictwo M, 2019.

Franciszek. Adhortacja apostolska Evangelii gaudium. Kraków: Wydawnictwo M, 2013.

Franciszek. Adhortacja apostolska Querida Amazonia. Kraków: Wydawnictwo M, 2020.

Jan Paweł II. Encyklika Redemptoris missio. Wrocław: Wydawnictwo Wrocławskiej Księgarni Archidiecezjalnej, 1995.

Jan Paweł II. Nowa ewangelizacja, postęp człowieka, kultura chrześcijańska. Przemówienie na otwarcie obrad IV Konferencji Ogólnej Episkopatu Ameryki Łacińskiej CELAM, Santo Domingo 12.10.1992 r. OsRomPol (1992) 13: 22-25.

Kowalczyk, Marian. „Zagrożenia wiary w dobie nowego ateizmu.” Współczesne zagrożenia wiary. Red. Jarosław Moskałyk. Poznań: Wydawnictwo Wydziału Teologicznego UAM, 2015. 39-58.

Krzemiński, Krzysztof. Wspólnota w Duchu. Historiozbawcze posłannictwo Ducha Świętego wedlug Heriberta Mühlena. Lublin: Wydawnictwo KUL, 2002.

Parzych-Blakiewicz, Katarzyna. Dialog - jako metoda ewangelizacji współczesnego świata wedlug Jana Pawta II. Olsztyn: Hosianum, 2000.

Paweł VI. Adhortacja apostolska Evangelii nuntiandi. Wrocław: Wydawnictwo Wrocławskiej Księgarni Archidiecezjalnej, 2001.

Pawłowski, Adam. Kerygmat w nowej ewangelizacji. Poznań: Wydawnictwo Agape, 2014.

Prado Flores, H. José. Nowi ewangelizatorzy dla nowej ewangelizacji. Tłum. Bronisław Jakubowski. Poznań: Wydawnictwo Święty Wojciech, 2013.

Projekt Pastoralny. Szkoła Ewangelizacji św. Andrzeja, Stryszawa 2011, s. 13. Dostęp 8 stycznia 2018. <http://www.snebytom.pl/wp-content/uploads/2015/02/ProjektPastoralnySESA.pdf $>$

Ryś, Grzegorz. Pierwsze jest pierwsze. Kraków: Wydawnictwo Studio, 2015.

Zborowski, Michał. „Kerygmat we współczesnych ruchach kościelnych.” Resovia Sacra (2019), s. 475-492.

Michaє ZвORowsKi, doktor teologii dogmatycznej, członek Towarzystwa Teologów Dogmatyków; zainteresowania naukowe: chrystologia pierwszych wieków, chrystologia kerygmatyczna i przepowiadana oraz nowa ewangelizacja. 
